\title{
Pulmonary Nonspecific Defense Mechanisms in Cystic Fibrosis I. Phagocytic Capacity of Alveolar Macrophages and Neutrophils
}

\author{
RAMÓN J. J. CASSINO, DANIEL O. SORDELLI, CARLOS N. MACRI, MARCELO KOHAN, \\ MARIO H. DILLON, AND OMAR H. PIVETTA ${ }^{(23)}$ \\ Centro Nacional de Genética Médica, Combate de los Pozos 2193, and Hospital de Niños "Dr. Ricardo Gutiérrez," $S$. \\ Bustamante 1399 Buenos Aires, Argentina
}

\begin{abstract}
Summary
Cystic fibrosis (CF) is the commonest cause of chronic obstructive lung disease within the first three decades of life. Because patients suffer from repeated pulmonary infections, we were interested in studying the nonspecific antibacterial mechanisms of the lungs of $\mathrm{CF}$ children. Fifteen $\mathrm{CF}$ children, 13 nontuberculous pulmonary-infected (I) children and 4 noninfected ( $N-1)$ children, who were diagnosed as having a foreign body in the air passages, were submitted to a bronchopulmonary washing. The absolute number, viability, and differential count of the cells were determined, and the phagocytic assay using the Lehrer's technique was carried out on the harvested cells.

The materials obtained from $\mathrm{CF}$ and I patients were mucopurulent, whereas the ones from the $\mathrm{N}$-I patients were not mucopurulent. The number of cells retrieved from $\mathrm{CF}$ and I patients was higher than that from the $\mathrm{N}-\mathrm{I}$ patients. This was attributed to an increase in the absolute number of polymorphonuclear leukocytes. The phagocytic capacity of polymorphonuclear leukocytes was not different for the three groups studied, whereas that of alveolar macrophages was higher for the $\mathrm{CF}$ and the I patients than for the $\mathrm{N}$-I ones. Inasmuch as there was no significant difference between the $C F$ and the I patients, we conclude that the nonspecific phagocytic behavior of alveolar macrophages and pulmonary polymorphonuclear leukocytes of $\mathrm{CF}$ patients might be similar to the one coming from other bacterial infectious states of the lung.
\end{abstract}

\section{Speculation}

Although cystic fibrosis children suffer from chronic progressive pulmonary infections, they show the normal population risk for other infections outside the lungs. Inasmuch as the immune system appears to be intact in these patients, a failure in one of the nonspecific antibacterial defense mechanisms of the lung may be considered.

The major cause of morbidity and mortality in cystic fibrosis (CF) is unquestionably the severe, chronic progressive pulmonary infections due to bacterial pathogens, particularly Pseudomonas aeruginosa and Staphylococcus aureus (18). An important feature of these infections is their striking localization in pulmonary tissue, with only very rare spread via the bloodstream to other sites of the body. Although this fact would tend to suggest that there is not a primary genetic defect in immunologic defense mechanisms in $\mathrm{CF}(4,11)$, the overwhelming role of infection in the disease has led to an exhaustive search for acquired or local pulmonaryimmunologic defect in this inherited disease.

The nonrespiratory activity of purifying inhaled air and keeping lung tissues free of infection has been collectively termed "lung host-defense mechanisms" (5); that includes mechanical barriers, mucociliary clearance, immunoglobulins, and inflammatory response involving polymorphonuclear leukocytes (PMN). In addition, the alveolar macrophages (AM) play a principal role during phagocytosis in the airways and during their scavenging activity on the alveolar surfaces (6).

Several studies $(7,17)$ have suggested the compartmentalization of cell-mediated immunity, i.e., both respiratory tract and systemic cell-mediated immunity exist and are relatively independent of each other. This concept would suggest an hereditary or acquired immunologic defect localized solely in CF lung.

Because of our interest in the lung defense mechanisms, the present study was undertaken to investigate the specific question of whether there are any defects in pulmonary AM and PMN nonspecific phagocytic function in $\mathrm{CF}$.

\section{SUBJECTS AND METHODS}

\section{SUBJECTS}

Fifteen CF patients, aged 1 to 17 years ( 9 females and 6 males) were studied with a diagnostic or therapeutic proposal; CF was diagnosed by clinical signs and by elevated sweat electrolytes; clinical grading according to Shwachman and Kulczycki score ranged from 65 to 90 . All the children were on normal diets and receiving appropriate therapy. Thirteen control subjects, aged 1 to 13 years ( 6 females and 7 males), were investigated for variable reasons and were subsequently found to have nontuberculous infectious pulmonary involvement and no positive sweat test. Four children who had no lung infection were also investigated; these subjects were diagnosed as patients with foreign body in airways; none received antibiotics for at least $48 \mathrm{hr}$ before bronchopulmonary lavage, and none was found to have a positive sweat test or CF familiar history.

These studies were carried out with the proper consent from parents of the children involved, according to the principles of the Declaration of Helsinki.

\section{CELL RETRIEVAL}

Under light general anesthesia achieved by inhalation of halothane (19), a rigid bronchoscope was introduced into the trachea and the main stem bronchi. A radiopaque catheter was passed through the bronchoscope as deeply as to the tip wedged into a segmental or subsegmental airway within a zone which previously had not shown any pathologic involvement to $\mathrm{X}$-rays.

Aliquots of sterile $0.15 \mathrm{M} \mathrm{NaCl}$ solution were alternatively instilled and withdrawn by gentle aspiration with a syringe. The total volume of washing solution to be instilled was determined according to the age and the lung size of the patient, calculated 
from radiologic parameters (range, 50 to $200 \mathrm{ml}$ ). The complete lavage procedure required approximately $5 \mathrm{~min}$, and there were no complications during or after performing it.

\section{PROCEDURE}

All samples of lung washing suspension were shaked vigorously during $2 \mathrm{~min}$; a $5-\mathrm{ml}$ aliquot was treated with $1 \mathrm{ml}$ of a $20 \%$ solution of $\mathrm{N}$-acetylcystein (20) and incubated $10 \mathrm{~min}$ at $37^{\circ} \mathrm{C}$ with constant shaking. The total number of cells, the viability as assessed by exclusion of trypan blue dye, and the differential cell count on smears obtained by sedimentation and Giemsa staining were determined.

The remainder of the material was sedimented 2 min at $1 \times g$ and decanted; the decanted solution was centrifuged $5 \mathrm{~min}$ at 200 $\times g$. The viability of these cells was not different from those of the $N$-acetylcystein-treated cells. From the pellet obtained, $4 \times 10^{5}$ cells were scattered in Leighton tubes in $1 \mathrm{ml}$ of tissue culture medium (21) added to $10 \%$ of fresh human serum obtained from a pool of normal subjects.

After $3 \mathrm{hr}$ incubation, the adhered cells were rinsed twice with warm tissue culture medium, and varying concentrations of $\mathrm{Can}$ dida albicans were added to give a cell:yeast ratio of 1:4, 1:6, 1:8, $1: 12$, and $1: 16$. In this way, a modified phagocytic assay of Lehrer (9) was carried out by incubating the cell-yeast mixture for 30 min. The results of phagocytic capacity were expressed for the two principal phagocytic cellular types (AM and PMN) as the number of Candida yeasts clearly engulfed per 100 cells.

When a pair of means for samples distributed normally had to be compared, a Student's $t$ test for independent samples was applied with significant levels of $P<0.01$ and $P<0.05$. If the samples were not distributed normally and there was no homoscedasticity, the Mann-Whitney $U$ test was applied (14).

\section{RESULTS}

The recovery of washing solution was more effective in $\mathrm{CF}$ patients than in the noninfected $(\mathrm{N}-\mathrm{I})$ ones; the scattering of the data from nontuberculous pulmonary-infected (I) individuals made impossible the detection of any difference between this group and the N-I patients (Table 1). The total number of free cells harvested by bronchial lavage (Table 1) was higher in the I patients and was attributed principally to a near 200 -fold increase in the absolute number of PMN, as is shown from the proportion

Table 1. Percentage of wash fluid recovered and total cell content and cell viability in wash fluid obtained by bronchopulmonary lavage in CF children and control subjects

\begin{tabular}{|c|c|c|c|c|c|c|}
\hline & \multicolumn{6}{|c|}{ Patients } \\
\hline & \multicolumn{2}{|c|}{$\mathrm{N}-\mathrm{I}(n=4)$} & \multicolumn{2}{|c|}{$\mathrm{CF}(n=15)$} & \multicolumn{2}{|c|}{ I $(n=13)$} \\
\hline & $\overline{\mathbf{x}}$ & Range & $\overline{\mathbf{x}}$ & Range & $\overline{\mathbf{x}}$ & Range \\
\hline $\begin{array}{l}\text { Recovery of } \\
\text { wash fluid (\%) }\end{array}$ & 29.80 & $20.0-38.0$ & $45.25^{1}$ & $27.5-58.8$ & 40.20 & $22.5-75.0$ \\
\hline Cell no. $\left(\times 10^{i b}\right)$ & 3.32 & $1.0-9.3$ & $49.63^{2}$ & $\begin{array}{l}14.4- \\
138.0\end{array}$ & $63.98^{2}$ & $\begin{array}{l}1.5- \\
144.0\end{array}$ \\
\hline Viability (\%) & 96.2 & $88-95$ & 90.4 & $80-100$ & 89.1 & $70-97$ \\
\hline
\end{tabular}

${ }^{1}$ Significantly different from the N-I patient group $(P<0.01)$.

${ }^{2}$ Significantly different from the N-I patient group $(P<0.05)$.

Table 2. Differential cell count made on Giemsa-stained smears obtained by sedimentation of samples of lung wash suspensions

\begin{tabular}{|c|c|c|c|c|c|c|}
\hline & \multicolumn{6}{|c|}{ Patients } \\
\hline & \multicolumn{2}{|c|}{$\mathrm{N}-\mathrm{I}(n=4)$} & \multicolumn{2}{|c|}{$\mathrm{CF}(n=15)$} & \multicolumn{2}{|c|}{$\mathrm{I}(n=13)$} \\
\hline & $\bar{x}$ & Range & $\overline{\mathbf{x}}$ & Range & $\overline{\mathbf{x}}$ & Range \\
\hline $\mathrm{AM}$ & 84 & $76-89$ & $16^{\prime}$ & $3-47$ & $20^{\prime}$ & $1-56$ \\
\hline $\begin{array}{c}\text { Foamy } \\
\text { cells }\end{array}$ & 4 & $1-10$ & 2 & $1-6$ & 1 & $0-4$ \\
\hline $\begin{array}{l}\text { Giant } \\
\text { cells }\end{array}$ & 4 & $2-7$ & 1 & $0-4$ & 2 & $0-7$ \\
\hline PMN & 7 & $4-11$ & $79^{\prime}$ & 43-94 & $75^{\prime}$ & $37-98$ \\
\hline Lymphocytes & 1 & $0-2$ & 1 & $0-4$ & 1 & $0-2$ \\
\hline Eosinophils & 0 & & 1 & $0-9$ & 1 & $0-4$ \\
\hline
\end{tabular}

${ }^{1}$ Significantly different from N-I patient group $(P<0.01)$

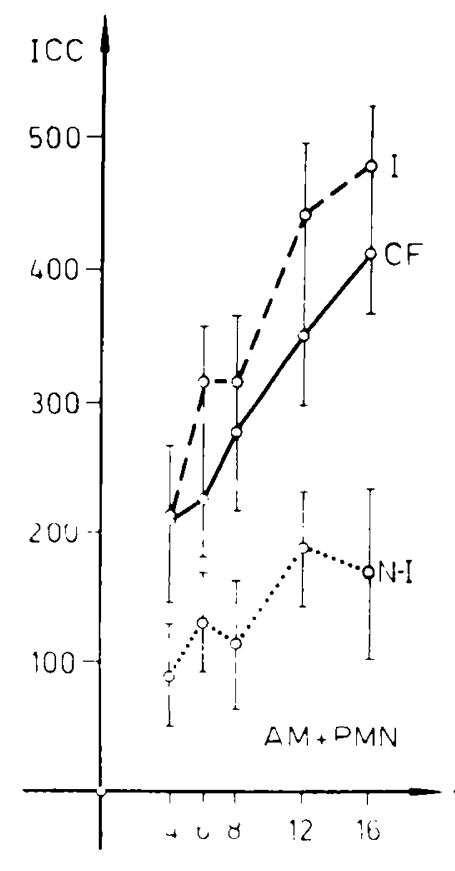

$\Delta$

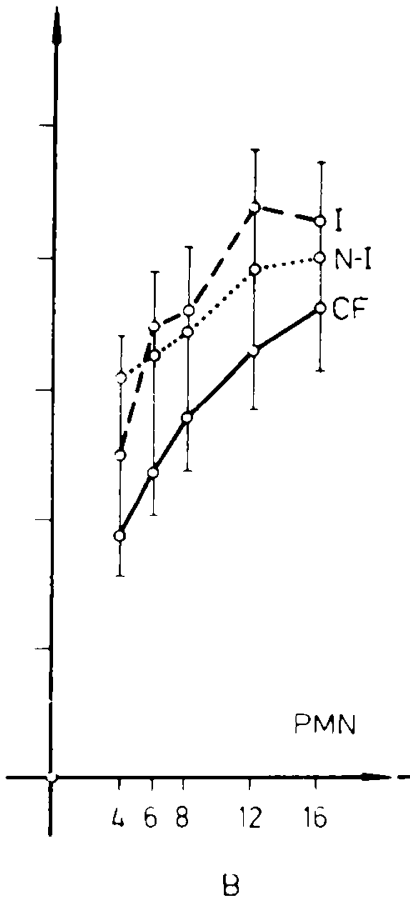

8

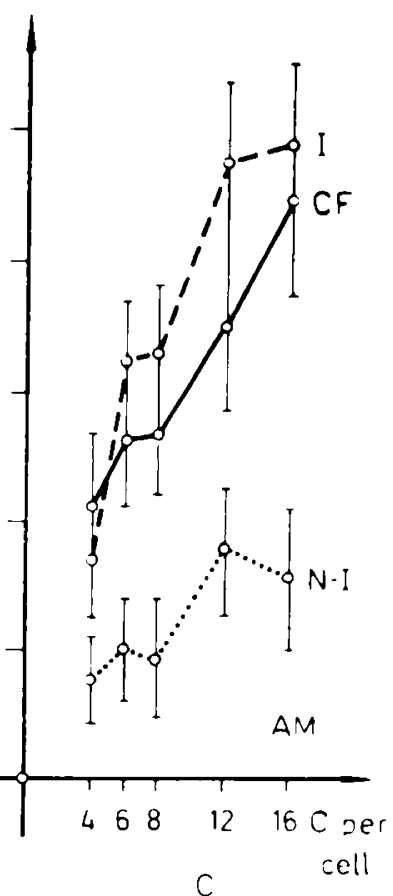

$\mathrm{C}$

Fig. 1. Relationship between the number of intracellular Candida per 100 lung cells $(I C C)$ and the number of yeast particles per cell, cultured for 30 min ( $C$ per cell). $A$, heavy mean values of the ICC engulfed by both AM and PMN together; $B$ and $C$, mean values of the ICC engulfed by PMN and AM, respectively. In all cases, $\bar{x} \pm S$.D. 
of these cells and AM (Table 2). The viability of the morphologically conserved cells (Table 1) was the same in the three groups; however, it must be noted that all the infected (CF and I) patients showed a high number of partially destroyed cells which were not included in the viability counting.

The phagocytic capacity of the total content of free cells in washing fluid was plotted against the inverse of the cell:yeast ratio, and the results are shown in Figure 1. Each point represents the heavy average of the number of cell-associated yeasts found in 100 phagocytic cells, namely AM and PMN. Recognition of the cell-associated Candida was easy, as shown in Figure 2.

Estimated values of phagocytic capacity overlapped in both infected (CF and I) patients, whereas all the N-I patients showed a lesser phagocytic capacity than the infected ones. This difference was not detected when the PMN were considered separately (Fig. $1 B$ ); in other words, the phagocytic capacity of PMN was not different for the three groups. However, the difference appeared again when the phagocytic capacity of the AM was studied in isolation (Fig. $1 C$ ). It can be noted that the differences were detected between infected (CF and $\mathrm{I}$ ) and noninfected patients and only attributed to the AM.
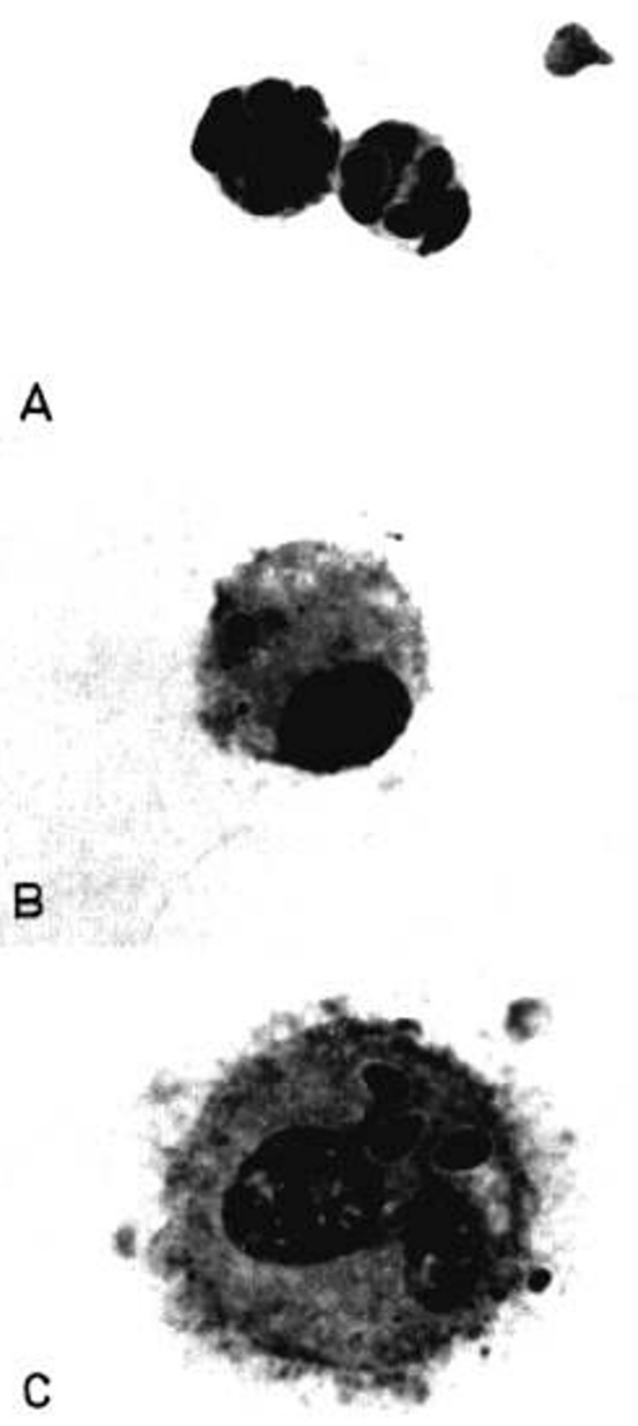

Fig. 2. Phagocytic cells of the respiratory tract of CF children. $A$, two PMN which have engulfed yeasts of $C$. albicans ( 4 and 3 yeasts in left and right PMN's, respectively); $B$, alveolar macrophage with one intracellular yeast; $C$, binucleated giant cell with 3 engulfed yeasts (sedimented cells stained with Giemsa, $\times 1250$ ).

\section{DISCUSSION}

During the last years, the involvement of AM in the antibacterial defense of the lungs (12) has been recognized as one of the most important mechanisms. Because CF patients suffer from persistent lung infection, the study of the lung defense mechanisms in these children has become more important each day, and the investigation in this field related to AM becomes a necessity. In this context, different approaches have been worked out, although the interest of these authors arose primarily in the study of the influence of possible phagocytic inhibitory factors in CF serum $(2,16)$ or in the decrease of serum factors which normally promote the engulfment of particles by normal nonhuman AM (1). Other studies have been developed to study the mechanisms of intracellular degradation of mucus by $\mathrm{AM}$ in CF patients; these results have not been confirmed yet $(3,10)$.

The present work was directed towards the analysis of the phagocytic capacity of AM and PMN harvested by bronchopulmonary washing of CF children.

Both the CF and the I patients had mucus hypersecretion, which was not only seen macroscopically but detected through the recovery of the wash solutions; this hypersecretion was less in $\mathrm{N}$ I patients than in the other two groups. Because the mucopurulent samples obtained were difficult to process, it was necessary to liquefy the suspensions with a mucolytic agent, whereas nontreated cells partially homogenized by shaking were preferred for functional studies.

As it has been described previously, both CF and I patients showed marked hypercellularity in lung-washing suspensions. This was due to PMN $(13,15)$. In view of the free cell content of airways, $\mathrm{CF}$ does not differ from other nontuberculous infectious states.

Because separation and purification of respiratory cells constitute a considerable technical problem, we decided to apply the method described by Lehrer (9) for evaluating simultaneously the nonspecific phagocytic capacity of AM and PMN.

When the total cell content was analyzed for phagocytic capacity, no significant differences between $C F$ and I patients were found, and in both cases, the cells were more effective than those from N-I patients. This clear difference may be well understood in terms of macrophage activation, which was produced in vivo in the infected lung environment. When AM and PMN were investigated separately, however, it was seen that this increase in phagocytic capacity was associated with AM only. The mean values of phagocytic capacity tend to be lower for CF than I patients in almost all the assays performed; however, the differences were not significant, probably due to the dispersion of the data. The results, therefore, indicate that the behavior of CF-AM might not be substantially different from those of the AM found in the airways of patients with nontuberculous infection.

The AM is the only tissue macrophage readily available for study, and therefore, it has been the main source of the relatively limited information on hand on macrophage function in human tissues (8). The present study deals only with the phagocytic cells which can adhere in $3 \mathrm{hr}$ and remain adherent during the assay procedure. Therefore, the results presented here should be carefully interpreted because the population of cells investigated may not be either the predominant one or representative of the in vivo whole organ.

Future studies regarding the evaluation of other CF-AM-specific mechanisms would provide further information related to the pathogenesis of the CF lung bacterial involvement.

\section{REFERENCES AND NOTES}

1. Biggar, W. D., Holmes, B.. and Good. R. A.: Opsonic defect in patients with cystic fibrosis of the pancreas. Proc. Natl. Acad. Sci. U. S. A., 68: 1716 (1971)

2. Boxerbaum, B., Kagumba, M. and Matthews, L. W. Selective inhibition of phagocytic activity of rabbit alveolar macrophages by cystic fibrosis serum. Am. Rev. Respir. Dis., 108: 777 (1973).

3. Cichocki. T., Litwin. J. A.. Szotowa, W., Hanicka, M., Gutkowski, P., Zebrak, J., and Czeczotko. E.: Histochemical observations on the pulmonary macrophages in cystic fibrosis. Z. Kinderheilkd.. 116: 127 (1974) 
4. di Sant'Agnese, P. A., and Davis, P. B.: Research in cystic fibrosis (third of three parts). N. Engl. J. Med., 295: 597 (1976).

5. Green, G. M.: The J. Burns Amberson Lecture. In defense of the lung. Am. Rev. Respir. Dis., 102: 691 (1970)

6. Green, G. M. Jakab, G. J., Low, R. B., and Davis, G. S.: State of the Art. Defense mechanisms of the respiratory membrane. Am. Rev. Respir. Dis., 115: 479 (1977).

7. Henney, C. S., and Waldman. R. H.: Cell-mediated immunity shown by lym phocytes from the respiratory tract. Science (Wash. D. C.), 169: 696 (1970)

8. Hocking, W. G., and Golde, D. W.: The pulmonary alveolar macrophage. N Engl. J. Med., 301: 580 (1979).

9. Lehrer, R. I.: Measurement of candidacidal activity of specific leukocyte types in mixed cell populations. I. Normal, mieloperoxidase-deficient, and chronic granulomatous diseases neutrophils. Infect. Immun., 2: 42 (1970).

10. McCarthy, C., Reid, L., and Gibbons, R. A.: Intra-alveolar mucus removal by macrophages with iron accumulation. J. Pathol. Bacteriol.. 87: 39 (1964).

11. Pennington. J. E.. Wolff, S. M., and Puzzis, M.: Summary of a workshop on infections in patients with cystic fibrosis. J. Infect. Dis., 140: 252 (1979).

12. Reynolds, H. Y.: Lung host defenses: a status report. Chest, 75: 239 (Suppl.: Immunology of the lung) (1979).

13. Sahu, S., and Lynn, W. S.: Lipid co. , osition of airway secretions from patients with asthma and patients with cystic fibrosis. Am. Rev. Respir. Dis., 115: 233 (1977).

14. Siegel, S.: Nonparametric statistics for the behavioral sciences. p. 116 (McGrawHill Book Co. and Kogakusha Co. Ltd., Tokyo, Japan, 1956).

15. Spock, A., Lanning, C. F., Kylstra, J. A., and Bell, D.: Composition of lavage fluid from patients with cystic fibrosis. Pediatr. Res. (Abstract). 13:541 (1979).

16. Thomassen, M. J., Boxerbaum, B., Demko, C. A., Kuchenbrod, P. J., Dearborn. D. G., and Wood, R. E.: Inhibitory effect of cystic fibrosis serum on Pseudomonas phagocytosis by rabbit and human alveolar macrophages. Pediatr. Res.. 1.3: 1085 (1979).

17. Waidman, R. H., and Henney, C. S.: Cell-mediated immunity and antibody response in the respiratory tract after local and systemic immunization. J. Exp. Med., 134: 482 (1971).

18. Wood. R. E., Boat, T. F., and Doershuk, C. F.: State of the art. Cystic fibrosis. Am. Rev. Respir. Dis., 113: 833 (1976).

19. Fluothane; Ici-Farma, Argentina.

20. Mucomyst; Mead-Johnson, Argentina.

21. Tissue culture (TC) 199; Difco Laboratories, Detroit, MI

22. The authors thank Dr. Tetsuji Matayoshi for his photographical advice and Susana Paz for her secretarial assistance.

23. Requests for reprints should be addressed to: Omar H. Pivetta, MD., Centro Nacional de Genética Médica, Combate de los Pozos 2193. 1245 Buenos Aires. Argentina.

24. Received for publication January 25, 1980

25. Accepted for publication May 14, 1980.

Printed in U.S.A. 